\title{
IMPACTED CISTERNA MAGNA WITHOUT SYRINGOMYELIA ASSOCIATED WITH LANCINATING HEADACHE, THROBBED NUCHAL PAIN AND PARAPARESIS TREATED BY POSTERIOR FOSSA DECOMPRESSION
}

\author{
José Alberto Gonçalves da Silva', Maria do Desterro Leiros da Costa, \\ Luiz Ricardo Santiago Melo', Antônio Fernandes de Araújo', \\ Everardo Bandeira de Almeida ${ }^{3}$
}

\begin{abstract}
A 29-year-old woman with acute lancinating headache, throbbed nuchal pain and subacute paraparesis underwent brain MRI in supine position that depicted: the absence of the cisterna magna, filled by non herniated cerebellar tonsils and compression of the brain stem and cisternae of the posterior fossa, which are aspects of the impacted cisterna magna without syringomyelia and without hydrocephalus. During eight days, pain was constant and resistant to drug treatment. Osteodural-neural decompression of the posterior fossa, performed with the patient in sitting position, revealed: compression of the brainstem, fourth ventricle and foramen of Magendie by herniated cerebellar tonsils, which were aspirated. Immediately after surgery, the headache and nuchal pain remmited. MRI depicted the large created cisterna magna and also that the cerebellar tonsils did not compress the fourth ventricle, the foramen of Magendie and the brainstem, besides the enlargement of posterior fossa cisternae. Four months after surgery, headache, nuchal pain and paraparesis had disappeared but hyperactive patellar and Achilles reflexes remained.
\end{abstract}

KEY WORDS: headache, nuchal pain, craniovertebral malformation, tight cisterna magna, impacted cisterna magna, Chiari malformation, posterior fossa decompression, paraparesis, herniated tonsils.

Cisterna magna impactada sem siringomielia associada a cefaléia lancinante, dor na nuca terebrante e paraparesia tratadas com descompressão da fossa posterior

RESUMO - Uma paciente de 29 anos de idade com quadro agudo de cefaléia lancinante, dor terebrante na nuca e paraparesia subaguda foi submetida a RM do encéfalo, em posição supina, que revelou: ausência da cisterna magna, preenchida por tonsilas cerebelares não herniadas e compressão do tronco encefálico e das cisternas da fossa posterior, compatíveis com o diagnóstico de cisterna magna impactada sem siringomielia e sem hidrocefalia. Por oito dias a dor foi constante e resistente aos analgésicos. Com a paciente em posição sentada, foi realizada descompressão osteodural-neural da fossa posterior associada a aspiração das tonsilas cerebelares. Os achados perioperatórios foram caracterizados por herniação das tonsilas cerebelares que comprimiam o tronco cerebral, o quarto ventrículo e o forame de Magendie. No pós-operatório imediato houve remissão da cefaléia e da dor na nuca. A RM evidenciou a cisterna magna recémcriada, alargamento do quarto ventrículo e das cisternas do tronco encefálico. Quatro meses depois, a paciente continuava sem cefaléia, sem dor na nuca e sem paraparesia. Entretanto, permaneceu a hiperatividade dos reflexos patelares e aquileus.

PALAVRAS-CHAVE: cefaléia, dor na nuca, malformação craniovertebral, cisterna magna impactada, tight cisterna magna, malformação de Chiari, descompressão da fossa posterior, paraparesia, tonsilas herniadas.

\footnotetext{
${ }^{1}$ Neurosurgical Unit of the Hospital Unimed, João Pessoa PB, Brazil; ${ }^{2}$ Federal University of Paraiba, João Pessoa PB, Brazil; ${ }^{3}$ Neuroanesthesist, João Pessoa PB, Brazil.

Received 3 April 2007, received in final form 17 August 2007. Accepted 17 September 2007.

Dr. José Alberto Gonçalves da Silva - Avenida Minas Gerais 1150 - 58030-og2 João Pessoa PB - Brasil. E-mail: jags1803@hotmail.com
} 
Many studies on craniovertebral malformations indicate that a specific, suboccipital headache of variable types and duration may affect the patients. In a retrospective study of 249 operated cases of craniovertebral malformations, Gonçalves da Silva' observed headache in 149 (59.8\%) and nuchal pain in 132 (53\%); Milhorat et al. ${ }^{2}$ studied 364 symptomatic patients with Chiari I malformation and found that the most common symptom was a suboccipital headache, experienced by 296 (81\%) patients, described as a heavy, crushing, or pressure-like sensation at the back of the head that radiated to the vertex and behind the eyes. A distinctive feature of this headache is the tendency to be increased by physical exertion, Valsalva maneuver, head dependency and sudden changes in posture. Their studies also demonstrated in most cases that Chiari-related headaches could be clearly distinguished from cervicogenic and other headache syndromes. Similar findings were reported by Pascual et al. ${ }^{3}$ that analyzed the headaches presented by 50 patients with Chiari I malformation. Of these $50,14(28 \%)$ had suboccipital-occipital headache. Headaches correlated to craniovertebral malformations affect predominantly the occipital-suboccipital region and are usually provoked by cough ${ }^{4,5}$. Stovner ${ }^{5}$ studied 34 patients with Chiari I malformation in order to understand the related headache symptoms, particularly the long-lasting attacks or continuous pain. He encountered 20 patients who had or had had headaches and interviewed them by way of a questionnaire. Ten patients had short term cough headaches lasting less than 5 minutes, 14 patients had relatively long-lasting attacks lasting from 3 hours to several days, and 8 patients had continuous headache. Unlike the short term cough headache attacks, long-lasting attacks were usually not precipitated by Valsalva-like maneuver and could be differentiated from those of migraine and cervicogenic headache patients. These characteristics associated with a positive effect of surgical treatment in some patients, suggest a causal relationship between the malformation and the headache. According to this author, this malformation may cause long-lasting headache attacks or continuous head pain by compression of the brainstem, central cord degeneration or intracranial hypertension.

Hans Chiari ${ }^{6,7}$ described four types of cerebellar anomalies, which later were named Chiari malformation (CM). Type I was characterized by downward displacement of the cerebellar tonsils and the medial portions of the inferior cerebellar lobes, which accompanied the medulla oblongata into the cervi- cal spinal canal. Type II showed downward displacement of portions of the cerebellum, and portions of the inferior vermis, pons, medulla oblongata and, at least, a part of the lengthened fourth ventricle, which reached the disc $\mathrm{C}_{4}-\mathrm{C}_{5}$, into the enlarged cervical spinal canal. In type III, the hydrocephalic cerebellum, pons and medulla were inside a cervical meningocele (hydroencephaloceles cerebellaris cervicalis), through a spina bifida of the first three cervical vertebrae. In type IV, there was hypoplasia of the cerebellum without herniation of the cerebellar structures into the spinal canal. Iskandar et al. ${ }^{8}$ related five cases of syringomyelia (SM), in which the cisterna magna was filled by the cerebellar tonsils. All five cases presented clinical improvement after decompression of the posterior fossa as well as marked reduction in the size of the syrinx. These authors admitted that this dramatic response to decompression indicated that this entity has a Chiari-like pathophysiology. Kyoshima et al. ${ }^{9}$ reported four similar cases with an improvement of symptoms and a reduction in the syrinx size in three patients and a reduction in ventricle size in one. These authors termed the cisterna magna impacted by the cerebellar tonsils "tight cisterna magna" and called the description according to Iskandar et al. ${ }^{8}$, "Chiari o malformation". Posterior fossa decompression for patients with this malformation is indicated when they present symptoms of compression syndromes of the brainstem and spinal cord, unusual headache types and other uncommon conditions ${ }^{4,5}$.

This study is based on the rareness of the clinical picture characterized by an excruciating headache, throbbed nuchal pain and paraparesis, associated with impacted cisterna magna without SM.

\section{CASE}

A 29-year-old woman, who works at the Emergency Department of Unimed Hospital presented an acute history of lancinating headache and throbbed nuchal pain which were resistant to dypirone, anti-inflammatory and opioid drugs for eight days. Despite the use of these drugs, pain was continous and according to the patient, reached 10 on the Pain Visual Analogical Scale. She also referred to a progressive loss of muscular strength of the lower limbs forcing her to give up her daily walking. The neurological exam presented paraparesis without spasticity and marked hyperactive patellar and Achilles reflexes. MRI depicted the absence of the cisterna magna, as well as a diminution of the fourth ventricle and of the superior and prepontine cisternae (Figs 1 and 2). Surgical treatment was indicated based on the impacted cisterna magna, the paraparesis and the non effective treatment of the pain. Osteodural-neural decompression of the posterior fossa was carried out with the patient in sitting position ${ }^{10}$ (Fig 3). During this procedure we observed the following abnormalities (Fig 4): compression of 


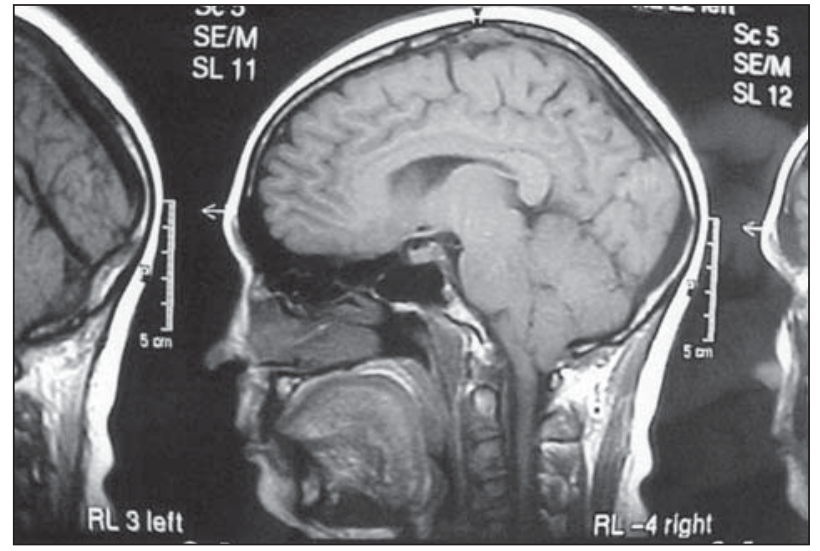

Fig 1. Preoperative sagittal MRI shows impacted cisterna magna, diminished fourth ventricle and superior and prepontine cisternae.

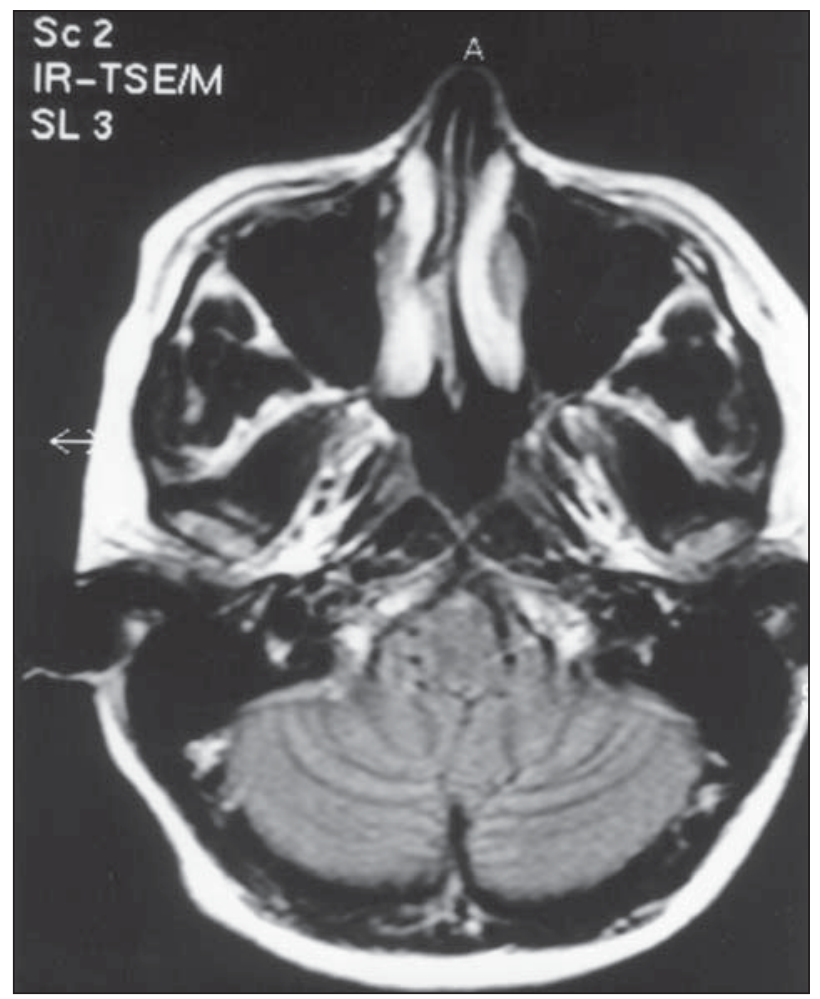

Fig 2. Preoperative axial MRI depicts the absence of the cisterna magna.

the fourth ventricle as well as the foramen of Magendie by the cerebellar tonsils which closed this foramen, filled the cisterna magna and migrated downwards into the cervical spinal canal (no adherences to the neighboring structures were observed). The left cerebellar tonsil was hypertrophic and reached the $\mathrm{C}_{2}$ level while the right was hypotrophic and situated at $\mathrm{C}_{1}$; the left posterior inferior cerebellar artery (PICA) was enlarged and descended to the C2 level, while the left PICA was hypoplasic. We performed intrapial aspiration of the cerebellar tonsils and made a large opening of the fourth ventricle (Fig 5), then sutured the residual pial sac upwards to the dura-mater in cranial lateral position and finally a dural grafting was made with bovine

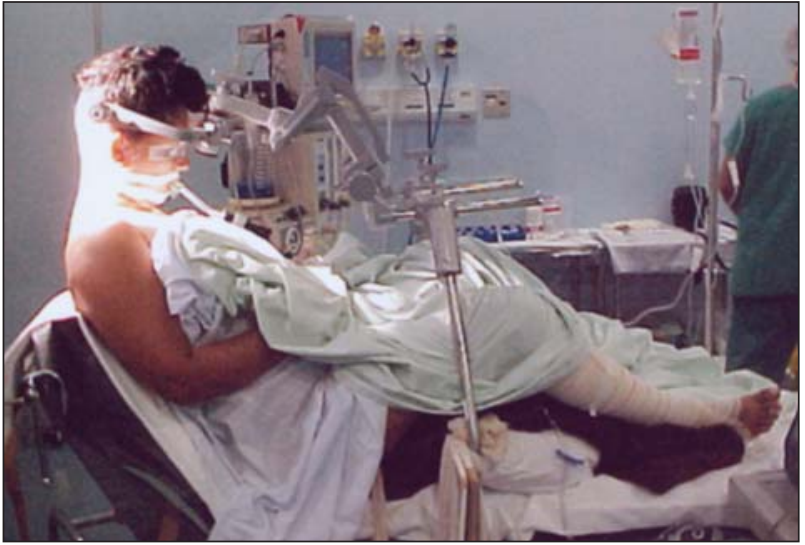

Fig 3. Patient in sitting position.

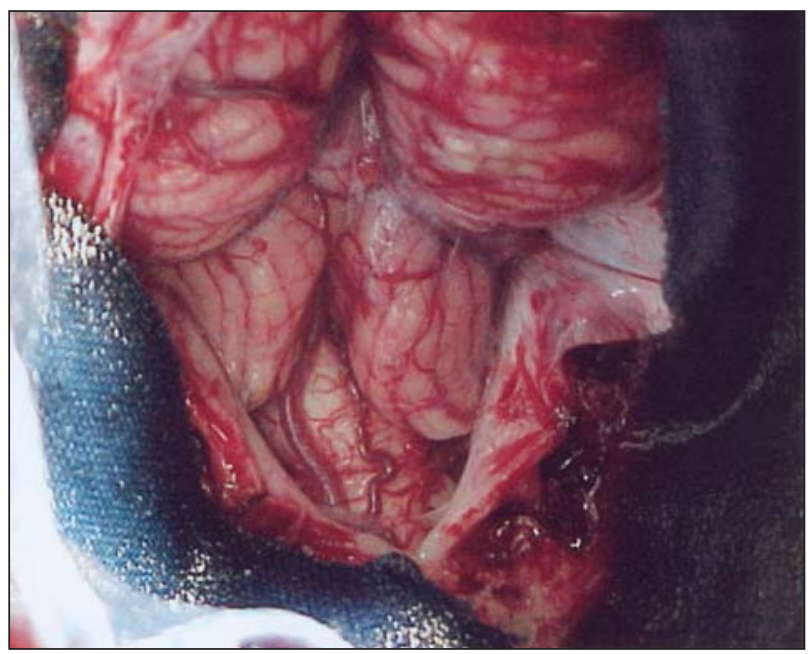

Fig 4. Tonsile herniation observed during the operation in sitting position.

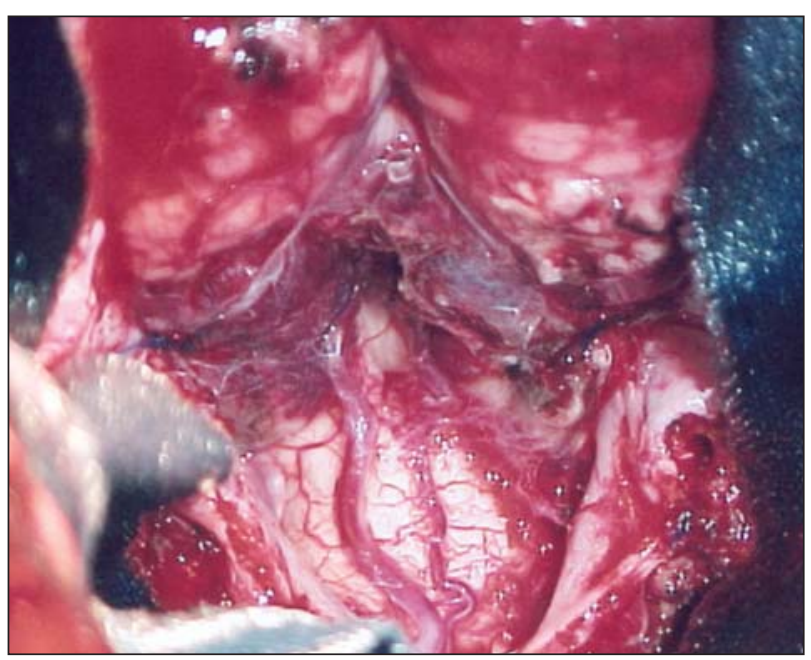

Fig 5. Tonsilectomy and large opening of the fourth ventricle.

pericardium. Ten days after the operation a cerebral spinal fluid (CSF) leakage through the surgical incision was diagnosed. The patient was reoperated and the CSF leak was repaired. The postoperative MRI (Fig 6) depicted the large created cisterna magna, enlargement of the fourth ventri- 


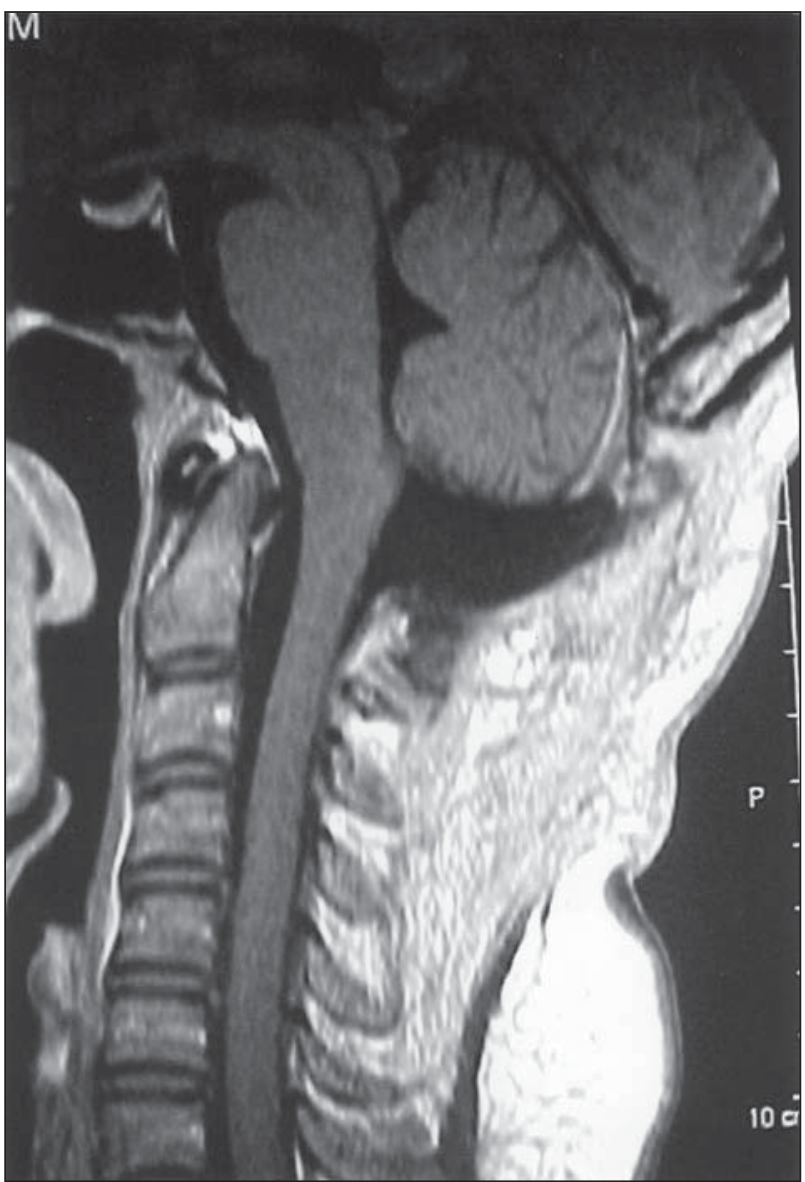

Fig 6. Postoperative sagittal MRI showing the new created cisterna magna, opening of the fourth ventricle and enlargement of the cisternae magna, and superior and prepontine cisternae.

cle as well as of the superior and prepontine cisternae, besides the absence of compression of the cerebellar tonsils towards the fourth ventricle and the foramen of Magendie. The headache and nuchal pain disappeared immediately after the operation. Four months later, the patient continued without headache, nuchal pain, paraparesis and returned to her job. Nevertheless, the hyperactive patellar and Achilles reflexes remained unchanged.

This study was approved by the Bioethics Research Committee.

\section{DISCUSSION}

The pathophysiological mechanisms that underlie headache and nuchal pain in craniovertebral malformations remain unclear. McGirt et al. ${ }^{11}$ studied 33 cases of Chiari I malformation, presenting with headaches alone, to identify the correlations between headache and CSF flow obstruction. The preoperative MRI of the craniovertebral junction was prospectively performed in all patients. They observed that regardless of the degree of tonsillar ectopia, occipital headaches were strongly associated with hindbrain CSF flow ab- normalities. Kesler and Mendizaval ${ }^{12}$ described two cases of diagnosed Chiari I malformation where the primary complaint was headache. These authors argue that CM should be considered in the differential diagnosis of patients who complain of exertional headaches.

To Arnett ${ }^{13}$, occipital and exertional headaches are associated with tonsillar ectopia encompassing slight descent of the cerebellar tonsils and Chiari I malformation. The headache in this malformation is secondary to pressure dissociation gradients and perhaps, traction of pain-sensitive tissues. According to this author, the extent of tonsillar descent alone is irrelevant. The degree of posterior fossa hypoplasia and decrease of the CSF flow velocity are more likely the causes of pain symptoms in tonsillar ectopia. On the other hand, Pascual et al. ${ }^{3}$ and Taylor et al. ${ }^{4}$ admitted that the headache and the nuchal pain are directly related to the degree of tonsilar herniation.

Occipital headache and nuchal pain are frequently observed in cases of craniovertebral malformations like basilar impression (BI), CM and $\mathrm{SM}^{1,2,14-16}$. In a retrospective study of $\mathbf{2 4 9}$ operated cases of craniovertebral malformations, Gonçalves da Silva ${ }^{1}$ observed headaches in 149 (59.8\%) and nuchal pain in $132(53 \%)$ in the pre-operatory phase. After decompression of the posterior fossa, headache was eliminated in 139 $(93.2 \%)$ of the 149 cases, while nuchal pain remmited in $121(91.6 \%)$ of the 132 cases.

Gonçalves da Silva et al. ${ }^{17,18}$ described two cases of impacted cisterna magna without tonsilar herniation depicted by MRI in supine position. Both cases presented headache and nuchal pain. During the operation, with the patient in sitting position, cerebellar tonsils herniation was detected. This finding indicates that in orthostatic position, cerebellar tonsils herniation may exert compression towards the upper cervical dorsal roots and distortion of the brainstem resulting in nuchal pain.

This study presents a rare case of impacted cisterna magna associated with lancinating headache and throbbed nuchal pain, at an intensity never identified before in any other patient of our casuistics referred above. The possible pathophysiological mechanisms to explain the severity of the pain is that the herniated cerebellar tonsils through the foramen magnum moving up and down could originate compression of the superior cervical spinal cord, cerebellum, medulla and friction of the first cervical roots. This mechanism, along with the described disturbance of CSF due to the compression of the foramen of Magendie, associated with the absence of cisterna magna could have 
resulted in headache and nuchal pain.

Iskandar et al. ${ }^{8}$ were the first to report five cases of SM without hindbrain herniation. All cases improved after the decompression of the posterior fossa and the authors suggested that this entity had a Chiari like pathophysiology. Kyoshima et al. ${ }^{9}$ published four similar cases with a good recovery of the patients after the decompressive operation of the posterior fossa. These authors named this malformation as "tight cisterna magna" and designated Iskandar's et al. ${ }^{8}$ description as "Chiari o malformation". According to Williams ${ }^{19}$, the cerebellar tonsils herniation may compress brainstem structures and contribute to bulbar and long tracts dysfunctions. In a similar way, the pressing of the cerebellar tonsils into the cisterna magna, without herniation into the cervical spinal canal, causes disturbances to the CSF flow at the foramen magnum and can also develop neurological symptomatology by compression of the brainstem. This author also admitted that tonsilar distortion, hindbrain herniation and obstruction of the outlet of the fourth ventricle may cause headache. In some cases, the foramen of Magendie is completely occluded by a membrane and hydrocephalus does not necessarily occur. Probably because of the drainage of the fourth ventricle via the foramen of Lushka.

In this case the foramen of Magendie, the fourth ventricle and the medulla oblongata were compressed by the impacted cerebellar tonsils. Probably the compression of the brainstem could explain the paraparesis in this case while the CSF hypertension in the posterior fossa could be responsible for the headache and nuchal pain.

Acknowledgements - The authors thank Mr. David Swingler, English Teacher, for the improvement of this manuscript.

\section{REFERENCES}

1. Gonçalves da Silva JA. Malformações occipitocervicais: impressão basilar, malformação de Chiari, siringomielia, platibasia. Recife: Editora Universitária/ UFPE, 2003.

2. Milhorat TH, Chou MW, Trinidad EM, et al. Chiari I malformation redefined: clinical and radiographic findings for 364 symptomatic patients. Neurosurgery 1999;44:1005-1017.

3. Pascual J, Oterino A, Berciano J. Headache in type I Chiari malformation. Neurology 1992;42:1 519-1521.

4. Taylor FR, Larkins MV. Headache and Chiari I malformation: clinical presentation, diagnosis and controversies in management. Curr Pain Headache Rep 2002;6:331-337.

5. Stovner LJ. Headache associated with the Chiari type I malformation. Headache 1993;33:175-181.

6. Chiari H. Über Veränderungen des Kleinhirns infolge von Hydrocephalie des Grosshirns. Dtsch med Wschr 1891;17:1172-1175.

7. Chiari H. Über Veränderungen des Kleinhirns, des Pons und der Medulla Oblongata in Folge von congenitaler Hydrocephalie des Grosshirns. Dtsch Akd Wiss 1895;63:71-85.

8. Iskandar BJ, Hedlund GL, Grabb PA, Oakes WJ. The resolution of syringohydromyelia without hindbrain herniation after posterior fossa decompression. J Neurosurg 1998;89:212-216.

9. Kyoshima K, Kuroyanagi T, Oya F, Kamijo Y, El-Noamany H, Kobayasi S. Syringomyelia without hindbrain herniation: tight cisterna magna: report of four cases and review of the literature. J Neurosurg (Spine 2)2002;96:239-249.

10. Gonçalves da Silva JA, Holanda MMA. Basilar impression, Chiari malformation and syringomyelia: a retrospective study of 53 surgically treated patients. Arq Neuropsiquiatr 2003;61:368-375.

11. McGirt MJ, Nimjee SM, Floyd J, Bulsara KR, George TM. Correlation of cerebrospinal fluid flow dynamics and headache in Chiari I malformation. Neurosurgery 2005;56:716-721.

12. Kesler R, Mendizabal JE. Headache in Chiari malformation: a distinct clinical entity? J Am Osteopath Assoc 1999;:153-156.

13. Arnett BC. Tonsillar ectopia and headaches Neurol Clin 2004;22:229-236.

14. Klaus E. Die basiläre Impression. Leipzig: S Hirzel, 1969.

15. Caetano de Barros M. Contribuição ao estudo da impressão basilar associada à malformação de Arnold-Chiari. Tese, Recife, 1959.

16. Arruda JAM. Tratamento da siringomielia associada à malformação de Chiari: análise de 60 casos. Tese, São Paulo, 2001.

17. Gonçalves da Silva JA, Leiros MD, Holanda MMA, Melo LRS, Araújo AF, Viana APB. Impacted cisterna magna without syringomyelia associated with spastic paraparesis: case report. Arq Neuropsiquiatr 2006;64:672-675.

18. Gonçalves da Silva JA, Holanda MMA, Leiros MD, Melo LRS, Araújo AF, Almeida EB. Basilar impression associated with impacted cisterna magna, spastic paraparesis and distress of balance: case report. Arq Neuropsiquiatr 2006;64:668-671.

19. Williams B. Surgery for hindbrain related syringomyelia. In Advances and technical standards in neurosurgery 1993;20:109-164. 